Article

\title{
Impact of Value Co-Creation on International Customer Satisfaction in the Airsoft Industry: Does Country of Origin Matter?
}

\author{
Gabriela Menet ${ }^{1, *}$ and Marek Szarucki ${ }^{2}$ (I) \\ 1 Department of Strategic Analyses, WSB University in Dąbrowa Górnicza, 41-300 Dąbrowa Górnicza, Poland \\ 2 Department of Strategic Analysis, College of Management Sciences and Quality, \\ Cracow University of Economics, 31-510 Krakow, Poland; szaruckm@uek.krakow.pl \\ * Correspondence: menet.gabriela@gmail.com
}

Received: 30 August 2020; Accepted: 21 September 2020; Published: 24 September 2020

check for updates

\begin{abstract}
The paper's objective is to investigate the impact of value proposition co-creation on international customer satisfaction in the airsoft industry. This empirical paper aims at answering a question "Which factors influence satisfaction of the international customers involved in the process of value co-creation in the airsoft industry" and sets a hypothesis that value co-creators' country of origin has a positive impact on customers' satisfaction. A case study approach of an entrepreneurial company (GATE) was supplemented with data collected via a survey $(\mathrm{n}=176)$, where consumers' perception of the firm's value proposition and its influence on their satisfaction were investigated. The study contributes to the value creation theory by identifying the main factors influencing customer satisfaction in the airsoft industry and verifying whether the co-creators' origin affects the factors' ratings. The results indicate that the most crucial factors influencing international customer satisfaction in this industry are quality level and product functionality and that the country of origin of customers has no significant impact on international customer satisfaction.
\end{abstract}

Keywords: airsoft industry; customer satisfaction; country of origin; entrepreneurship; value co-creation; value proposition

\section{Introduction}

Recently, there has been an observable growth of importance of value as a subject of broad debate among scientists and practitioners. Value creation is considered to be a key concept in the management and organization literature for both macrolevel (organization theory, strategic management) and microlevel (individual, group) research (Lepak et al. 2007). It can be linked not only to entrepreneurship (Dyduch 2019) and organizational ideology (Jaki and Siuta-Tokarska 2019), but also macroeconomics and public investments (Berawi and Woodhead 2020). Nevertheless, the process of how value is formed as well as the assessing and the capture of value is difficult and challenging (Gray 2006; Nickerson et al. 2007; Chatain 2011; Cunningham et al. 2018). Conservatively, it was assumed that value was created by the firm and streamed to the customer. Lately, it has been acknowledged that creation of value is in fact a co-operative value creation process that arises between the customer and the firm. This shift evidently highlights the increasing significance of customers and their resource contributions towards value creation (Priem 2007). Moreover, customer involvement in a value co-creation process (Etgar 2008) leads to an improvement in the value of a product and results in an increase in customer satisfaction and loyalty (Banyte and Dovaliene 2014; Agrawal and Rahman 2015; Cossío-Silva et al. 2016). By attracting customers in the product design process, companies provide tailored solutions that meet individual customers' needs and prevent product failures (Luchs et al. 2016). Until now, very few studies have 
investigated entirely customer involvement at this stage (Menguc et al. 2014), especially at the international level. Discovering this crucial issue would improve companies' identification of novel product ideas, which builds extra value for international customers (Najafi-Tavani et al. 2020).

Some academics have already explored the influence of country of origin on customers' service expectations (Seger-Guttmann et al. 2017) and proved that the customers have varying expectations due to cultural differences. Thus, enterprises shall take into consideration that these vast differences in expectations depending on country of origin may affect sales and shall be considered while designing a marketing strategy. Other researchers analyzed cultural influences on evaluations of service quality (Albu 2013; Guesalaga et al. 2016). One very recent study has investigated the impact of cultural distance on relationship learning on international customer involvement in the context of a manufacturing company in China and its international customers. The results proved that there are far more benefits from the relationship learning capabilities for suppliers when they share a similar culture with customers, and that cultural differences remarkably diminish the effectiveness of international customer involvement on company performance (Najafi-Tavani et al. 2020). However, to our best knowledge, there are no studies investigating the impact of country of origin on international user satisfaction in technology-based firms.

The main research purpose of this paper is to explore the impact of value proposition co-creation on international customer satisfaction in the airsoft industry. The airsoft industry was selected especially because this niche market has been developing fast in recent years and airsoft guns have lately received a boost in consumer enthusiasm (McGee 2017). Nevertheless, literature investigating the relationships between satisfaction and customer involvement in the process of value co-creation in high-tech companies is scarce (Hsieh and Hsieh 2015). There is some evidence in the scientific literature that a few academics have researched the airsoft topic, however, the focus has been directed mostly towards possible injuries deriving from improper use of airsoft guns (Haavisto et al. 2019; Saunte and Saunte 2006, 2008), the impact of Amazon on distribution in the airsoft market (Acocella and Zhu 2017), and technical aspects of airsoft guns' functioning (Do Duc et al. 2016; Horák et al. 2014). Thus, there is a need for deep marketing-oriented research on airsoft, which would also improve the field of management. Starting with the matter of value and customer satisfaction, the research results may prove to be crucial for the strategies of businesses operating in the airsoft market (Szarucki and Menet 2018).

The paper contributes to the theory and practice of value co-creation in at least two ways. Firstly, by proving that the main factors influencing international customer satisfaction in the analysed industry are quality level and product functionality. Secondly, by testing the set hypothesis and providing evidence that the country of origin of customers does not influence international customer satisfaction significantly.

The structure of the paper includes the theoretical background divided into three parts: (1) the essence of value and value propositions, (2) delivered value and customer satisfaction, and (3) value proposition creation and co-creation. After that, the materials and methods are described. The last three sections of the article focus on the results, discussion and conclusions.

\section{Theoretical Background}

\subsection{Essence of Value and Value Propositions}

Value is an ubiquitous concept that appears in many different fields of knowledge: from philosophy and ethics, through social sciences, physics, chemistry, mathematics, economics and many others (Sánchez-Fernández and Iniesta-Bonillo 2007). The theoretical considerations of value cover such terms as: economic value, market value, exchange value, utility value, functional value, psychological value, creative value and emotional value. In marketing and management theory, the value proposition has been introduced as a statement that summarizes the reason for a consumer's purchase decision. In addition, many companies, consciously or not, use a so called "value-focused approach", which helps them to specify the exact consumers' needs and therefore to easily meet them. 
There are plenty of definitions of value being found in different fields of science (philosophy, ethics, medicine, mathematics or economics). Nevertheless, due to the objective of the paper, it is necessary to take a deeper look at different types of value that appear in the management and organization literature (Bowman and Ambrosini 2000; Sánchez-Fernández and Iniesta-Bonillo 2007; Barnes et al. 2009; Frow and Payne 2011; Osterwalder et al. 2014; Goedhart et al. 2015; Deng 2019). The typology of value is rich and encompasses, among others, the following important sorts of value: creative value, economic value, market value, emotional value, psychological value, exchange value, utility value, functional value and company value.

Creative value may be defined as "the value added to the customer when using the breakthrough idea for the first time" (Yang and Sung 2011). This type of value can also be understood as the value of creative content, which has never appeared before and is added to a product or service. The next, very important type of value is economic value, which means the financial benefit a customer obtains when using a product or service (Gupta and Lehman 2005). In other words, it is the maximum amount of money a customer is able to pay for the delivered value. The economic value is always larger than the market value. It is important to distinguish the market value from the economic one. Usually, the market value represents not the maximum but the minimum price a consumer is willing to pay. It is sometimes used interchangeably with open market value and fair value. However, in some contexts, the definition may vary, e.g., Boyce $(1975$, p. 137) defines the market value as "the highest price in terms of money which property will bring in a competitive and open market under all conditions requisite to a fair sale, the buyer and seller each acting prudently and knowledgeably, and assuming the price is not affected by undue stimulus". Thus, the general definition is different than the specific one connected with the real estate market. Another category of value is emotional value, which is associated with the perception of emotions, human interactions, as well as emotional exchanges, and is a part of studies on cognition and emotions (Hareli and Hess 2012). On the contrary, the psychological value is the benefits associated with the intangible values of the product or service, such as brand names (Gupta and Lehman 2005). Next is exchange value, which derives from the political economy and constitutes one of the attributes of a commodity, i.e., a product or service manufactured for, and sold on, the market. The other three aspects are utility value, economic value, and price (Howard 2011). There is also a specific kind of exchange value-advertising exchange value, which "is related to consumers' evaluation of a specific medium in regard to the importance of the content and their attitudes toward the advertising associated with the medium" (Kelty 2013, p. 7). Thanks to the value-in-use, a customer receives economic, financial or social value. The functional value is defined as "the practical benefits a customer receives from the performance or the features of the product or service" (Gupta and Lehman 2005). The firm value can be equal to the sum of the market value of tradable shares, the market value of non-tradable shares and the market value of debt, divided by the total assets (He and Zhang 2019). In this paper, value is analyzed from the customer perspective, thus we follow the definition of Bowman and Bowman and Ambrosini (2000) as the subjective valuation of consumption benefits by a consumer. Understanding value is very important for both value proposition creation and constructing the strategic plan for a company.

The research problem analyzed in this paper is situated within the theory of organization and management, thus, when mentioning the term "value proposition", the value should be perceived according to Camlek (2010, p. 119) as "worth in usefulness or importance to the possessor; utility or merit'.

The ability of companies to recognize and introduce value propositions perceived as desirable on their target markets is commonly regarded as a key to competitive success (Anderson et al. 1993; Lanning 1998; Covin et al. 2015). Every business has a value proposition. As noticed by Morris et al. (2005, p. 729): "There is no business without a defined value proposition, and the creation of value provides a justification for the business entity". In their study, Kaplan and Norton (2004, p. 10) explored the concept of value proposition and stated that "strategy is based on a differentiated customer value proposition. Satisfying customers is the source of sustainable value creation. Strategy requires a 
clear articulation of targeted customer segments and the value proposition required to please them. Clarity of this value proposition is the single most important value of strategy". Therefore, the value proposition itself is a very important concept for every company that wants to expand. In the 1970s and 1980s, a similar attitude was directed towards quality, which is an essential element of value delivered in a product. There was a conviction that quality must be built into the offering (including all the products and services sold). Thus, the Total Quality Management approach has much in common with value propositions and managing customer value (Barnes et al. 2009, p. 21).

The concept of the value proposition emerged in the 1980s. First, Bower and Garda (1985), and later, Lanning and Michaels (1988), highlighted the importance of communicating the value in products and offerings. Lanning (1998) defined the "value proposition" as the essence of the business and believed that a business is a value delivery system. In Lanning's theory, the value proposition is "about customers but for your organization; not addressed to customers but must drive these communications; defines exactly what the organization fully intends to make happen in the customer's life" (Barnes et al. 2009, p. 22). Originating from a supplier's point of view, and compliant with a goods-dominant logic, the expansion of the value proposition consists of three main steps: "choose the value, provide the value, and communicate the value" (Kowalkowski et al. 2012, p. 1555). From this viewpoint, the value proposition concept can be treated similarly to a marketing offer. In recent years, scholars noted that the value proposition concept is elusive and usually not defined clearly. It was signified that "only recently have value propositions evolved from earlier value delivery and value exchange contexts to the ecosystem context" (Riihimäki et al. 2016, p. 66). Next, value co-creation arose as a process in which stakeholders create value jointly (Prahalad and Ramaswamy 2013).

The value proposition will be perceived as "the benefits customers can expect from your products and services" (Osterwalder et al. 2014). This definition provides the most proper basis for later research, which aims at developing the value existing in the eyes and beliefs of customers. Now, it is necessary to introduce the notion of the value-focused approach and the value-focused enterprise. At the heart of the value-focused business approach lie value propositions. In the value-focused enterprise, the value inputs start with the strategic goal and are carried throughout the whole organization. The value proposition is inserted into the core of the business model, and is the basis of the business. It is crucial for everyone in the company, starting from the chief executive officer and ending with recently employed workers (Barnes et al. 2009, pp. 40-41).

\subsection{Delivered Value and Customer Satisfaction}

Nowadays, customer satisfaction is a crucial indicator of a company's competitiveness. Not only tangible but also intangible aspects form customer satisfaction. It is not a simple task to make customers satisfied, especially because everyone has different emotional reactions, a distinct character and values different things. A situation that would make one pleased can make somebody else anxious. The feeling of satisfaction appears only in the moment when consumers' needs and expectations are completely met. The increase in rivalry among competitors led to making customers more demanding than they were before. However, every company that wants to succeed must focus its marketing activities on creating value, which makes customers more satisfied and attracts more loyal consumers. If the service satisfies the customers, the purchase frequency increases while a reduction in the search for alternatives occurs (Yang et al. 2014).

For many years, customer satisfaction has been seen as the key element, which makes it possible to explain why customers resign from the products or services of a company, move towards competitors or stay (Cohen et al. 2006). A company should satisfy its customers in order to achieve success in a particular market, no matter whether it produces goods or services and no matter whether those are business to businessor business to customerrelations. The notion of satisfaction derives from the Latin language: satis-enough, and facere - to make, which can be understood as making something sufficiently so as the expectations of somebody are met (Fornell 1992). Customer satisfaction is connected not only with the product itself, but also with the particular brand and post-sale experience. 
There are many different definitions of customer satisfaction. Olivier (1980) defines it as the emotional response to a product or service that a customer took advantage of. According to Giese and Cote (2000), it is a reaction (cognitive and emotional), which focuses particularly on the experience of the client associated with the purchase of a product and is present at a given time (e.g., after the purchase or consumption). Satisfaction can be understood as the reaction of a customer to a product or service, as the level of fulfillment of the customer's needs and expectations, as the feeling of a consumer connected with purchasing a particular good, as well as a factor that is significant for creating a company's value.

Different factors may influence the customer satisfaction among which the delivered value that has to meet the customers' expectations is situated. In service industry, these factors include: efficiency, availability, fulfillment, privacy, responsiveness and contact (Jo and Mo 2018), whereas, in the case of products, it might be price, promotion, product reliability, brand image, health concern and perceived value (Pattarakitham 2015). In particular, the perceived value is highlighted by academics as extremely important when researching customer satisfaction and loyalty (Scridon et al. 2019; Servera-Francés and Piqueras-Tomás 2019). A company may deliver perfect value at a reasonable price, but if the value does not meet the customers' needs, it is useless and has no impact on the company's growth. According to Riihimäki et al. (2016, p. 67), it is important to note that "the nature of value propositions was always exhibited and analyzed in network context". Despite many difficulties, there was a necessity of further research on the impact of value perception on buyer behavior (Gronroos and Voima 2013). Indeed, marketers put a lot of effort into understanding the customer perception of value (of both individual and institutional buyers) to develop policies, which would help them to capture the perceived value (Aitken and Paton 2016). This led Aitken and Paton (2016) to conduct a comparative analysis of how the wider, psychological needs of customers interact with the effects of business goals. Moreover, there is even the concept of customer-centric focus, which describes "how organizational strategies are combined with consumer needs to generate profit by maximizing the lifetime value of the customer" as "in the end the success of the product is often considered before the need of the customer; but even if a product performs functionally according to its specifications, it will be unsuccessful in the market place if it does not address a real customer need" (Van der Merwe et al. 2015, p. 61). Kessler et al. (2001) developed the concept of vasa syndrome, a term well known in marketing and management studies that is connected with a project failure resulting from insufficient communication. In principle, it refers to the necessity for identifying and addressing the customer needs.

The connection between value and customer satisfaction is a basis for one of the quality measurement tools: Kano's model. The model divides product attributes into the following categories: must-be attributes, one-dimensional attributes, attractive attributes, indifferent attributes, and reverse attributes (Van der Merwe et al. 2015, p. 63). Yang (2005) improved Kano's model into a Refined Kano's model in order to take into account a customer's perception of the degree of importance of a quality attribute.

According to the theory, as the one-dimensional attributes are better fulfilled, customer satisfaction is improved. That is because a one-dimensional attribute is equal to the linear relation between a customer's perception that the attribute will meet their needs and the attribute's ability to fulfill them. Thus, as better fulfillment of one-dimensional attributes raises the customer satisfaction, a company, which would like to improve the satisfaction of its clients, shall focus on those attributes. On the other hand, the low value-added quality attributes do not impact significantly on customer satisfaction, but their absence may cause customer dissatisfaction. The lack of "Must-be" quality attributes leads to complete customer dissatisfaction. Must-be attributes of high importance are "critical" quality attributes. When present, the "Reverse" quality attributes lead to total customer dissatisfaction and customer satisfaction when absent. The "Potential" quality attributes are indifferent but highly important. They have the potential to become attractive quality attributes. Companies should definitely avoid the care-free quality attributes. When present, the "Attractive" quality attributes mean the greatest customer satisfaction, but are not expected by customers to be found in a product. Attractive attributes of high importance are "highly attractive" quality attributes, an organization's strategic 
offerings, which attract new customers. Low attractive quality attributes can be eliminated in cost versus quality trade-offs (Van der Merwe et al. 2015, p. 63).

Osterwalder et al. (2014, p. 48), in their study, noticed that the "fit between what a company offers and what customers want is the number one requirement of a successful value proposition". The scholars distinguished three kinds of fit: (1) Problem-Solution Fit (on paper)—when a company strives to identify customer needs; (2) Product-Market Fit (in the market) -when a company strives to validate or invalidate the assumptions underlying its value proposition; (3) Business Model Fit (in the bank) - a great value proposition without a sound business model may lead to failure. The three kinds of fit interact with each other. However, the fit might be much harder to achieve when the customers are not only local, but also international—the distinction that many studies highlight (Rozian Sanib et al. 2013, pp. 297-313; Pluta-Olearnik 2016, pp. 266-75; Khan 2019, pp. 117-29). The term "international customers" is often used in the context of customers clearly from various cultural backgrounds (Wang et al. 2015, pp. 96-104).

\subsection{Value Proposition Creation and Co-Creation}

Studies on value started with the research of added value, followed by value chain investigation, superior value, perceived value, relationship value, stakeholder value and value in-use (Payne and Holt 2001; Woodruff 1997; Sánchez-Fernández and Iniesta-Bonillo 2007; Agrawal and Rahman 2015). Frow and Payne (2014, p. 214) argue that "developing a superior value proposition is a clear strategic imperative for enterprises". The process of value creation should start in the beginning stages of business foundation and then, as the company develops, the value shall be reassessed and often recreated. Vargo and Lusch (2004), when describing the theory of Service-Dominant (S-D) Logic, claimed that companies cannot unilaterally create, develop and deliver value to clients by turning knowledge into products, but they can only devise value propositions. Many believe that value propositions should be developed in cooperation with consumers through the process of reciprocally exchanging knowledge (Kowalkowski et al. 2012, p. 1554). Nevertheless, it is obvious that building on individual experience and context, users and sellers will have different views about what is valuable (Frow and Payne 2014). Therefore, the creation of a value proposition frequently means bundling distinctive, sometimes conflicting interests among actors. A firm must integrate and align different resources to become valuable. According to Lerro (2011), a company that is managed in an integrated way succeeds through value formation and fulfills the needs of its stakeholders through the creation, execution and control of accurate value propositions. Due to the main objective of the paper, below we concentrate on the co-creative practice approach and technology approach.

There is a growing interest among researchers in value co-creation (Galvagno and Dalli 2014; Saha et al. 2020). Kambil et al. (1996) introduced the term "value co-creation" to emphasize the role of customers in business strategy and marketing. Then it was popularized and disseminated by Prahalad and Ramaswamy $(2000,2004)$, who theorized value co-creation as the "co-creation of personalised experiences with the customers". In their study, Kowalkowski et al. (2012, p. 1554) provided a deepened understanding of complexities that are inherent in a co-creative practice of value proposition formation. They believed that the theoretical section should be accompanied by practice. Therefore, they labelled and identified the activities of the reciprocal exchange of knowledge. The scholars empirically illustrated how resource-integrating actors apply, assess, adapt and adopt knowledge when co-creating a customer-loyalty card. Moreover, other academics suggest that managers of small and medium-sized enterprises (SMEs) shall improve their procedures relating to knowledge formation through market sensing, learning and entrepreneurial orientation, as the appropriate attitude towards knowledge may positively impact on a company's growth (Alshanty and Emeagwali 2019).

Forming a value proposition should be portrayed as an exchange of knowledge between a group of resource-integrating actors who possess distinct understandings, procedures and engagements. The understandings are defined as "the practice-related knowledge (know-how), skills, and experiences of each resource-integrating actor", the procedures are "the practice-related rules, principles, 
and cultural norms of each resource-integrating actor", whereas the engagements should be understood as "the practice-related wants and needs, goals, and purposes to which each resource-integrating actor is committed" (Kowalkowski et al. 2012, p. 1563). Each of the resource-integrating actors gives some inputs during the formation of a value proposition. Through application, they provide inputs. Assessing is connected with input evaluation. Altering the inputs is named "adapting", whereas "adopting" refers to the inputs' acceptance.

There would be no co-creative practice of forming value proposition without knowledge exchange. Brown et al. (2007) described the reciprocal knowledge exchange as something "between either wholly inductive or completely confirmatory". The foundation of process is based on the theory of knowledge creation and sharing, which was developed by Nonaka and Takeuchi (1995) as well as widely-known literature on knowledge management, represented, e.g., by Alavi and Leidner (2001) or Davenport and Prusak (1998). Taking into consideration their theories, the exchange of knowledge can be characterized as a sequential process in which the knowledge is assessed, gathered, interpreted and used. It is also important to highlight who can be considered as a resource-integrating actor (Kowalkowski et al. 2012, p. 1559).

In order to depict the influence of technology on value creation, it is necessary to define the notion of technology commercialization. According to Davila (2000), technology commercialization means the application of modern technology to improved or new products and services, which are successfully sold in customer markets. Nowadays, technology commercialization is very important, because much technological potential is unused (Swamidass 2012). Technology commercialization may take place in corporations, large companies, SMEs, as well as at universities or non-profit organizations (Sideri and Panagopoulos 2018). In our paper, technology-based firms will be analyzed. There is no universal definition of technology-based firms (Wouters and Kirchberger 2015). However, these firms can be characterized as (Groen et al. 2015): (1) being managed by a small group of experts, (2) being focused on exploiting a technologically innovative idea, (3) being independent of already established companies. Technology commercialization shall be considered in the context in which it is a result of collaboration and knowledge integration of different companies (Wouters and Kirchberger 2015). It derives from the fact that a key success factor for new technology is connected with the benefits that it will deliver to users, especially in comparison to the existing solutions (Galbraith et al. 2006). Therefore, the new products or services should be created through the connection of technology and application, in such a way that they are valuable to users. However, the knowledge necessary for making the connections is dispersed across: (1) different departments in the organization; (2) different organizations; (3) potential customers, or customers of those customers; (4) development partners of the new technology-based firm; (5) others who may know about competing technologies, regulation, and societal challenges (Wouters and Kirchberger 2015, p. 54). Every party does not fully understand the context of other parties, so collaboration should be interactive. The process of collaboration should not limit itself to listening or learning from customers, it should be focused on gaining knowledge together with customers and understanding the issues that are not understood by the customers.

The impact of technology on value creation is also visible in different areas: marketing (advertising), sales, logistics, customer relationships management, post-sale service or distribution (Akaka and Vargo 2014; Breidbach and Maglio 2016; Wang et al. 2016). Technology affects the efficiency of individual processes, changing the nature of the links of each value chain and ultimately creates new opportunities for meeting the needs of consumers both at the level of product and price (which is the cost to the customer), distribution (the convenience of purchase) or promotion (which is a form of communication with the market and a way to provide consumers with information). The information technology (IT) sector has an especially large impact on value creation in the context of international customers (Jean et al. 2010).

Based on the conducted literature review, we have noticed that the only research in the social sciences field that was conducted so far with reference to the airsoft industry was connected with the impact of playing airsoft on airsoft players' lives (Roşu 2015). We found no studies concerning 
products or companies in the airsoft industry and how value co-creation influences international customers involved in that process. Based on the analysis of this theory, we have developed one research question and one hypothesis in order to explore the topic of satisfaction of international customers being involved in co-creative practices of value creation of a firm from the airsoft industry. Our study investigates the question: What are the most important factors influencing international customer satisfaction in the airsoft industry? Our main hypothesis is: $(\mathrm{H})$ : Value co-creators' country of origin has a positive impact on customers' satisfaction.

\section{Materials and Methods}

\subsection{Case Background}

In this research, we apply a case study approach defined as "revelatory" (Yin 2009). The case of the GATE Enterprise Sp. z o.o. Sp. k. (GATE) is well adapted to our research objective as the company applies its own strategy of involving its worldwide target customers into the process of value co-creation. Furthermore, the company grows very fast; its sales in 2017 increased by $180 \%$ in comparison to 2016, even though at that time GATE had not invested much in marketing activities. The spectacular results of the company are the product of successful value co-creation. Thus, we state that our case study is adequate and the information can be applied in similar situations. Moreover, as mentioned previously, we were unable to find relevant literature on how businesses in the airsoft industry exploit the impact of customer involvement in value co-creation on their satisfaction with the delivered product.

The research was conducted in the niche market of hobby items, on airsoft players who are customers of a small entrepreneurial enterprise. The GATE company is a technology-based firm founded in 2008. This particular company was selected as it is a firm with an interesting business model that generates the majority of turnover from customers abroad. However, the crucial point is that the GATE is characterized by a high level of innovativeness and invests around $20 \%$ of sales value in R\&D. In 2017, employing more than 30 people, the company put an emphasis on value co-creation and even moved toward hiring some of its customers. The company operates in the airsoft industry. Its business model assumes designing and producing electronic systems, which are then inserted by users or technicians in airsoft guns' gearboxes. The products are known as 'MOSFETs' or Airsoft Electric Gun (AEG) controllers and serve as guns' upgrades. Moreover, GATE makes high-end software applications for Android and iOS, which allow airsoft players to control their guns with smartphones and check statistics therein. The highest sales are recorded in the USA, Hong Kong, Western Europe and Japan. GATE sells mainly to international distributors and airsoft stores.

GATE has been practicing the theory of co-creating a value proposition for several years. GATE's strategy of value creation is in line with the model of co-creative practice of forming a value proposition proposed by Kowalkowski et al. (2012). In 2017, the company involved its customers in value co-creation through engaging them in a survey, which contained questions important for future value formation. The other example of the co-creative practice of forming a value proposition is the case of beta-testers. Before a product release, almost 50 beta-testers verify the product's prototype. They give the valuable feedback and help to improve the final version of the product. Thanks to them, some new functions can be introduced as well as product adjustments, making the final product almost perfect. The co-creative practice of forming a value proposition in GATE might be crucial for the company's further success. Figure 1 depicts a suggestion for co-creating value in the future. It would engage not only the beta-testers and customers (airsoft players), but also airsoft technicians and product designers (e.g., programmers). 


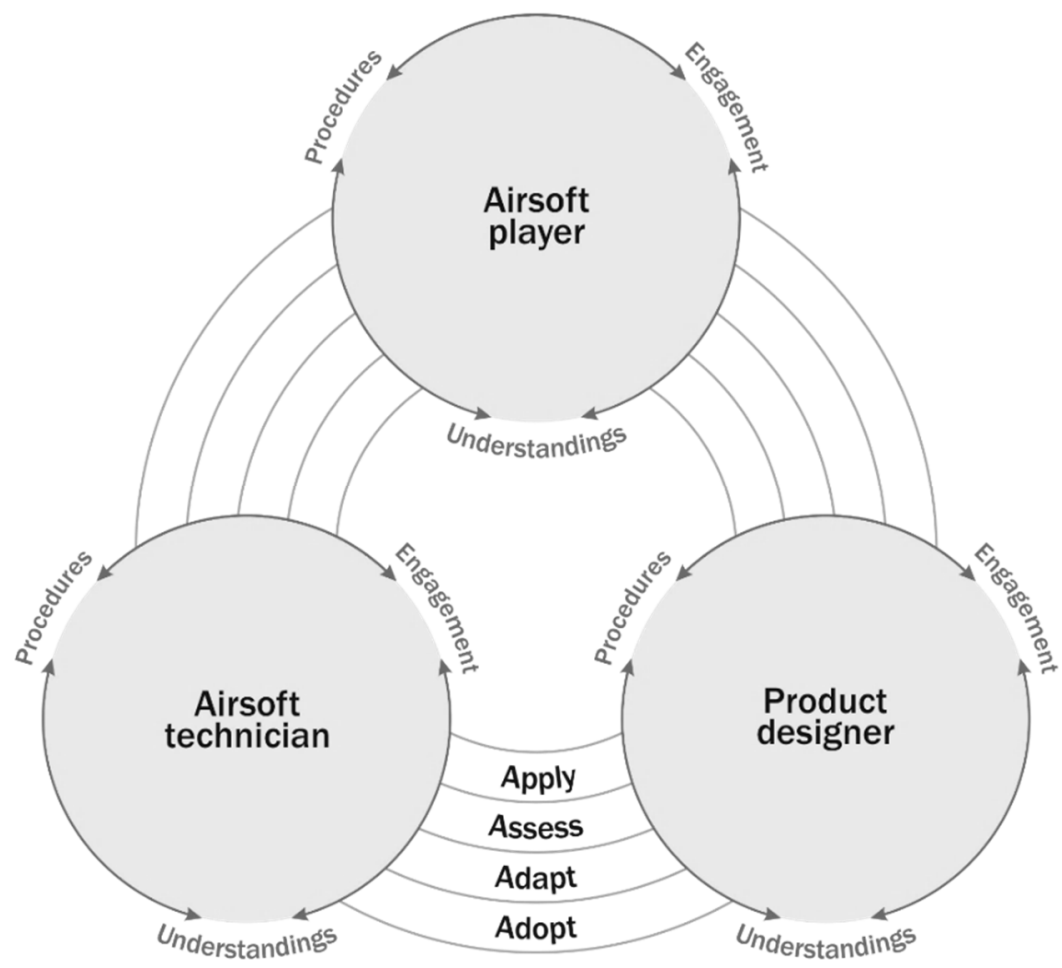

Figure 1. A co-creative practice of forming a value proposition in GATE. Source: own elaboration based on Kowalkowski et al. (2012, p. 1556).

However, this research focuses on one kind of resource-integrating actor: the airsoft player. It assumes that, based on collaboration with airsoft hobbyists from all around the world, the company can create unique value and technology, which adequately address the customer needs and influence the customer satisfaction in positive way. This strategic perspective is in line with research conducted by many prominent researchers, such as Prahalad and Ramaswamy (2000, 2004), Yang et al. (2014), Hsieh and Hsieh (2015).

Technology is part of GATE culture and philosophy. GATE can be treated as a technology-based firm, as it is being managed by several experts, it focuses on exploiting innovative ideas in terms of technology, and is totally independent of other already established companies. GATE applies modern technology to both improved and new products, which the company successfully sells in the global airsoft market. Therefore, technology commercialization is an everyday activity that takes place in the company. Most of company's products are sold online, and the purchase orders are made via email or the GATE online store. The detailed PDF product manuals with modern graphics are available on the company website. In addition, the company introduced the GATE Control Station computer app (GCS), which was very innovative way to configure the functions of its flagship products-TITAN and ASTER. The GCS turned out to be a key success factor for new technology in GATE. The app delivered new solutions to users, solutions that were never introduced before by other companies. The GCS is a mix of technology and application, and the app received very good opinions among customers all over the world. In 2020, the enterprise has planned to implement wireless connection in its product, which is its next important step toward using new technologies in airsoft. GATE is also aware of the importance of interactive collaboration with customers. This is why the company strives to co-create value with airsoft players. Thus, thorough research on value co-creation, value proposition and customer satisfaction was conducted. 


\subsection{Sample and Sources of Data}

The analysis was carried out in April 2017 by means of the Google docs' Internet survey. The survey questions are included in the Appendix A. A total of 1033 customers from the GATE database were contacted with the link to the survey. 479 of them opened the email. In addition, the survey appeared on the GATE Facebook fanpage, reaching 5717 airsoft players. The campaign started on the 12th of April 2017 and lasted for 11 days. The answers and valid data were gathered from 178 people from all over the world. The highest number of representatives originated from the USA, UK and France. The respondents who took part in the research represented more than 30 countries from four continents. Those were: Europe (69.1\%), North America (21.3\%), Asia (8.4\%) and South America (1.2\%).

The measures of customer satisfaction used in the research are as follows: brand name, product functionality, quality level, packaging, design, warranty period, after-sales service, manuals, company website, tutorial videos, ease of installation, price, promotions and advertising. The measures were chosen as they represent the marketing mix of product, price, place and promotion in the airsoft industry (Szarucki and Menet 2018). The respondents' origin was divided into four geographical areas: Asia, European Union, North America and Others.

\subsection{Methods}

The methods used were specifically chosen for this kind of study. The statistical analysis was performed using an application PQStat (version 1.6.2.901). The evaluation of factors influencing customer satisfaction was measured by calculating the arithmetic average, standard deviation, minimum, lower quartile, median, upper quartile and maximum of the pre-defined elements. The received values allowed for distinguishing the key aspects that affect customer satisfaction in the airsoft industry. In order to check the impact of geographical area of origin, the above measures of tendencies in a data set were extended by Kruskal-Wallis's Test and a post-hoc (Dunn-Bonferroni) test. Significance was assumed to be at $p<0.05$ and high significance was assumed to be at $p<0.01$.

The survey questions are a result of thorough analysis of the theoretical background and take into consideration the strategic perspective of the company and its business objectives. There were 27 questions divided into seven categories: (1) Respondent's data; (2) Products and functions; (3) Manuals; (4) Price; (5) GATE; (6) Airsoft; (7) Satisfaction. Many of those questions include Likert-scales (mostly 1-5), where customers could rate the answers and options.

\section{Results}

The GATE company employed more than 10 professionals in its R\&D department in 2017. The department is the core of the company, combining creativity with innovativeness and knowledge. The R\&D activities are connected with the new product design, prototyping, graphic design, user experience design as well as improving hardware and software. The survey questions concerned new product functions, factors influencing customer satisfaction in the particular industry, reasons for choosing this sport and detailed metrics. The survey results are the basis for strategic decisions in new product design.

In the survey, respondents had to evaluate factors shaping customer satisfaction in the airsoft industry. The chosen approach to scaling responses is the Likert-type scale (1-5). The higher the number, the more important the particular factor is for the airsoft players. Factors' assessment allowed depicting the answer to the research question (Table 1): What are the most important factors influencing international customer satisfaction in the airsoft industry? 
Table 1. Assessment of the factors influencing international customer satisfaction in the airsoft industry. Source: own elaboration $(\mathrm{n}=176)$.

\begin{tabular}{|c|c|c|c|c|c|c|c|}
\hline Measures & 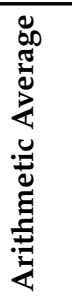 & 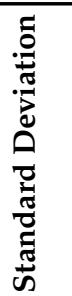 & 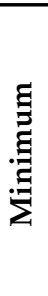 & 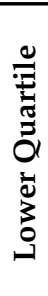 & $\frac{\pi}{\tilde{J}}$ & 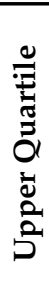 & 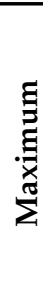 \\
\hline Brand name & 3.17 & 1.20 & 1 & 2 & 3 & 4 & 5 \\
\hline Product functionality & 4.76 & 0.46 & 3 & 5 & 5 & 5 & 5 \\
\hline Quality level & 4.83 & 0.40 & 3 & 5 & 5 & 5 & 5 \\
\hline Packaging & 2.93 & 1.27 & 1 & 2 & 3 & 4 & 5 \\
\hline Design & 3.69 & 1.06 & 1 & 3 & 4 & 5 & 5 \\
\hline Warranty period & 4.03 & 1.11 & 1 & 3 & 4 & 5 & 5 \\
\hline After-sales service & 4.29 & 0.85 & 1 & 4 & 4 & 5 & 5 \\
\hline Manuals & 4.04 & 0.92 & 1 & 3 & 4 & 5 & 5 \\
\hline Company website & 4.02 & 0.97 & 1 & 3 & 4 & 5 & 5 \\
\hline Tutorial videos & 4.06 & 1.01 & 1 & 3 & 4 & 5 & 5 \\
\hline Ease of installation & 4.21 & 0.92 & 1 & 4 & 4 & 5 & 5 \\
\hline Price & 3.70 & 0.96 & 1 & 3 & 4 & 4 & 5 \\
\hline Promotions and advertising & 3.99 & 1.12 & 1 & 3 & 4 & 5 & 5 \\
\hline
\end{tabular}

According to the above results, the most important factors influencing customer satisfaction are: quality level, product functionality and after-sales service. This answered the scientific question set in this paper: "What are the most important factors influencing customer satisfaction in the airsoft industry?". Knowing this, the GATE company can design an appropriate marketing plan, focusing on the crucial factors and paying less attention to the satisfaction factors that received lower ratings.

Table 2 shows the arithmetical analysis of answers to the survey question regarding the rating of factors influencing customer satisfaction in the airsoft industry, according to the geographical area of respondent origin. The purpose of the analysis was to verify whether the customer's origin might influence the assessment of a particular satisfaction factor in the airsoft industry. The airsoft market is specific, as the hobby is forbidden in some countries, which impacts sales. Since 2008, GATE has been distributing its products in more than 30 countries. Nevertheless, there was a question as to whether the marketing strategy should be oriented globally, or targeted depending on the place to which products are being sold. This is why the Kruskal-Wallis one-way analysis of variance was carried out. The non-parametric method for testing whether samples originate from the same distribution was extended by POST-HOC (Dunn-Bonferroni) tests. As a result, no significant $(p>0.05)$ difference has been proved. This means that the hypothesis "Value co-creators' country of origin has a positive impact on customers' satisfaction" is false, as we did not find any correlation between the country of origin and customer satisfaction. Thus, GATE decided to implement the marketing strategy of not dividing its marketing activities for particular geographical areas. The change in marketing strategy saved considerable costs and made it quicker and easier to run marketing operations. Before, GATE had spent an important part of its marketing budget on creating different marketing plans depending on the areas of origin. The co-creative practice of forming a value proposition turned out to be crucial in the company's development. 
Table 2. Ratings of the scales "Rate each of the elements according to the importance" depending on the continent from which the value co-creator originates. Source: own elaboration $(n=176)$.

\begin{tabular}{|c|c|c|c|c|c|c|c|c|c|c|c|c|c|}
\hline & & \multirow{2}{*}{$\begin{array}{l}\text { Arithmetic } \\
\text { Average }\end{array}$} & \multirow{2}{*}{$\begin{array}{c}\text { Standard } \\
\text { Deviation }\end{array}$} & \multirow[b]{2}{*}{ Minimum } & \multirow{2}{*}{$\begin{array}{c}\text { Lower } \\
\text { Quartile }\end{array}$} & \multirow[b]{2}{*}{ Median } & \multirow{2}{*}{$\begin{array}{l}\text { Upper } \\
\text { Quartile }\end{array}$} & \multirow[b]{2}{*}{ Maximum } & \multirow{2}{*}{$\begin{array}{l}\text { Kruskal-Wallis's } \\
\text { Test }\end{array}$} & \multicolumn{4}{|c|}{ POST-HOC (Dunn-Bonferroni) } \\
\hline & & & & & & & & & & Asia & EU & $\begin{array}{c}\mathrm{N} . \\
\text { America }\end{array}$ & Other \\
\hline \multirow{4}{*}{ Brand name } & Asia & 3.33 & 1.18 & 1 & 3.00 & 3 & 4.00 & 5 & \multirow{4}{*}{$\begin{aligned} \mathrm{H} & =0.74 \\
p & =0.86\end{aligned}$} & & 1 & 1 & 1 \\
\hline & EU & 3.12 & 1.19 & 1 & 2.00 & 3 & 4.00 & 5 & & 1 & & 1 & 1 \\
\hline & N. America & 3.24 & 1.20 & 1 & 2.25 & 3 & 4.00 & 5 & & 1 & 1 & & 1 \\
\hline & Other & 3.25 & 1.58 & 1 & 2.50 & 3.5 & 4.25 & 5 & & 1 & 1 & 1 & \\
\hline \multirow{4}{*}{$\begin{array}{l}\text { Product } \\
\text { functionality }\end{array}$} & Asia & 4.73 & 0.46 & 4 & 4.50 & 5 & 5.00 & 5 & \multirow{4}{*}{$\begin{aligned} \mathrm{H} & =4.46 \\
p & =0.22\end{aligned}$} & & 1 & 1 & 1 \\
\hline & EU & 4.74 & 0.50 & 3 & 5.00 & 5 & 5.00 & 5 & & 1 & & 0.46 & 1 \\
\hline & N. America & 4.89 & 0.31 & 4 & 5.00 & 5 & 5.00 & 5 & & 1 & 0.46 & & 0.61 \\
\hline & Other & 4.63 & 0.52 & 4 & 4.00 & 5 & 5.00 & 5 & & 1 & 1 & 0.61 & \\
\hline \multirow{4}{*}{ Quality level } & Asia & 4.93 & 0.26 & 4 & 5.00 & 5 & 5.00 & 5 & \multirow{4}{*}{$\begin{aligned} \mathrm{H} & =2.67 \\
p & =0.45\end{aligned}$} & & 1 & 1 & 1 \\
\hline & EU & 4.79 & 0.45 & 3 & 5.00 & 5 & 5.00 & 5 & & 1 & & 1 & 1 \\
\hline & N. America & 4.89 & 0.31 & 4 & 5.00 & 5 & 5.00 & 5 & & 1 & 1 & & 1 \\
\hline & Other & 4.88 & 0.35 & 4 & 5.00 & 5 & 5.00 & 5 & & 1 & 1 & 1 & \\
\hline \multirow{4}{*}{ Packaging } & Asia & 3.27 & 1.03 & 1 & 3.00 & 3 & 4.00 & 5 & \multirow{4}{*}{$\begin{aligned} \mathrm{H} & =4.38 \\
p & =0.22\end{aligned}$} & & 1 & 1 & 0.23 \\
\hline & $\mathrm{EU}$ & 2.93 & 1.30 & 1 & 2.00 & 3 & 4.00 & 5 & & 1 & & 1 & 0.52 \\
\hline & N. America & 2.97 & 1.26 & 1 & 2.00 & 3 & 4.00 & 5 & & 1 & 1 & & 0.56 \\
\hline & Other & 2.13 & 1.25 & 1 & 1.00 & 2 & 2.50 & 4 & & 0.23 & 0.52 & 0.56 & \\
\hline \multirow{4}{*}{$\begin{array}{l}\text { Design (how the } \\
\text { product looks like) }\end{array}$} & Asia & 4.07 & 0.96 & 2 & 3.50 & 4 & 5.00 & 5 & \multirow{4}{*}{$\begin{array}{l}\mathrm{H}=2.68 \\
p=0.44\end{array}$} & & 0.81 & 1 & 1 \\
\hline & EU & 3.63 & 1.07 & 1 & 3.00 & 4 & 4.00 & 5 & & 0.81 & & 1 & 1 \\
\hline & N. America & 3.76 & 1.02 & 1 & 3.00 & 4 & 5.00 & 5 & & 1 & 1 & & 1 \\
\hline & Other & 3.38 & 1.30 & 1 & 2.75 & 4 & 4.00 & 5 & & 1 & 1 & 1 & \\
\hline \multirow{4}{*}{ Warranty period } & Asia & 4.33 & 0.98 & 2 & 4.00 & 5 & 5.00 & 5 & \multirow{4}{*}{$\begin{aligned} \mathrm{H} & =2.75 \\
p & =0.43\end{aligned}$} & & 1 & 1 & 0.94 \\
\hline & EU & 4.08 & 1.07 & 1 & 3.00 & 4 & 5.00 & 5 & & 1 & & 1 & 1 \\
\hline & N. America & 3.84 & 1.28 & 1 & 3.00 & 4 & 5.00 & 5 & & 1 & 1 & & 1 \\
\hline & Other & 3.75 & 1.04 & 2 & 3.00 & 4 & 4.25 & 5 & & 0.94 & 1 & 1 & \\
\hline \multirow{4}{*}{ After-sales service } & Asia & 4.47 & 0.74 & 3 & 4.00 & 5 & 5.00 & 5 & \multirow{4}{*}{$\begin{aligned} \mathrm{H} & =0.85 \\
p & =0.84\end{aligned}$} & & 1 & 1 & 1 \\
\hline & EU & 4.29 & 0.84 & 1 & 4.00 & 4 & 5.00 & 5 & & 1 & & 1 & 1 \\
\hline & N. America & 4.24 & 0.94 & 1 & 4.00 & 4.5 & 5.00 & 5 & & 1 & 1 & & 1 \\
\hline & Other & 4.25 & 0.71 & 3 & 4.00 & 4 & 5.00 & 5 & & 1 & 1 & 1 & \\
\hline \multirow{4}{*}{$\begin{array}{c}\text { Manuals } \\
\text { (user-friendly } \\
\text { and multilingual) }\end{array}$} & Asia & 4.53 & 0.74 & 3 & 4.00 & 5 & 5.00 & 5 & \multirow{4}{*}{$\begin{aligned} \mathrm{H} & =5.90 \\
p & =0.12\end{aligned}$} & & 0.22 & 0.13 & 0.45 \\
\hline & EU & 4.06 & 0.83 & 2 & 4.00 & 4 & 5.00 & 5 & & 0.22 & & 1 & 1 \\
\hline & N. America & 3.84 & 1.15 & 1 & 3.00 & 4 & 5.00 & 5 & & 0.13 & 1 & & 1 \\
\hline & Other & 3.88 & 0.99 & 3 & 3.00 & 3.5 & 5.00 & 5 & & 0.45 & 1 & 1 & \\
\hline
\end{tabular}


Table 2. Cont.

\begin{tabular}{|c|c|c|c|c|c|c|c|c|c|c|c|c|c|}
\hline & & \multirow{2}{*}{$\begin{array}{c}\text { Arithmetic } \\
\text { Average }\end{array}$} & \multirow{2}{*}{$\begin{array}{l}\text { Standard } \\
\text { Deviation }\end{array}$} & \multirow[b]{2}{*}{ Minimum } & \multirow{2}{*}{$\begin{array}{c}\text { Lower } \\
\text { Quartile }\end{array}$} & \multirow[b]{2}{*}{ Median } & \multirow{2}{*}{$\begin{array}{c}\text { Upper } \\
\text { Quartile }\end{array}$} & \multirow[b]{2}{*}{ Maximum } & \multirow{2}{*}{$\begin{array}{c}\text { Kruskal-Wallis's } \\
\text { Test }\end{array}$} & \multicolumn{4}{|c|}{ POST-HOC (Dunn-Bonferroni) } \\
\hline & & & & & & & & & & Asia & EU & $\begin{array}{c}\mathrm{N} . \\
\text { America }\end{array}$ & Other \\
\hline \multirow{4}{*}{ Company website } & Asia & 4.20 & 0.77 & 3 & 4.00 & 4 & 5.00 & 5 & \multirow{4}{*}{$\begin{array}{l}\mathrm{H}=1.06 \\
p=0.79\end{array}$} & & 1 & 1 & 1 \\
\hline & EU & 3.97 & 1.00 & 1 & 3.00 & 4 & 5.00 & 5 & & 1 & & 1 & 1 \\
\hline & N. America & 4.11 & 0.98 & 2 & 3.00 & 4 & 5.00 & 5 & & 1 & 1 & & 1 \\
\hline & Other & 3.88 & 0.99 & 2 & 3.75 & 4 & 4.25 & 5 & & 1 & 1 & 1 & \\
\hline \multirow{4}{*}{ Tutorial videos } & Asia & 4.40 & 0.83 & 3 & 4.00 & 5 & 5.00 & 5 & \multirow{4}{*}{$\begin{aligned} \mathrm{H} & =5.93 \\
p & =0.12\end{aligned}$} & & 1 & 1 & 0.11 \\
\hline & EU & 4.08 & 1.04 & 1 & 3.00 & 4 & 5.00 & 5 & & 1 & & 1 & 0.26 \\
\hline & N. America & 4.00 & 0.99 & 2 & 3.00 & 4 & 5.00 & 5 & & 1 & 1 & & 0.61 \\
\hline & Other & 3.38 & 0.92 & 2 & 3.00 & 3 & 4.00 & 5 & & 0.11 & 0.26 & 0.61 & \\
\hline \multirow{4}{*}{ Ease of installation } & Asia & 4.73 & 0.46 & 4 & 4.50 & 5 & 5.00 & 5 & \multirow{4}{*}{$\begin{array}{l}\mathrm{H}=6.85 \\
p=0.08\end{array}$} & & 0.21 & 0.07 & 0.41 \\
\hline & EU & 4.23 & 0.86 & 2 & 4.00 & 4 & 5.00 & 5 & & 0.21 & & 1 & 1 \\
\hline & N. America & 3.97 & 1.13 & 1 & 3.00 & 4 & 5.00 & 5 & & 0.07 & 1 & & 1 \\
\hline & Other & 4.00 & 1.07 & 2 & 3.75 & 4 & 5.00 & 5 & & 0.41 & 1 & 1 & \\
\hline \multirow{4}{*}{ Price } & Asia & 3.47 & 1.13 & 1 & 3.00 & 3 & 4.00 & 5 & \multirow{4}{*}{$\begin{aligned} \mathrm{H} & =3.62 \\
p & =0.31\end{aligned}$} & & 1 & 0.73 & 1 \\
\hline & EU & 3.65 & 0.96 & 1 & 3.00 & 4 & 4.00 & 5 & & 1 & & 0.54 & 1 \\
\hline & N. America & 3.95 & 0.93 & 2 & 3.00 & 4 & 5.00 & 5 & & 0.73 & 0.54 & & 1 \\
\hline & Other & 3.75 & 0.71 & 3 & 3.00 & 4 & 4.00 & 5 & & 1 & 1 & 1 & \\
\hline \multirow{4}{*}{$\begin{array}{l}\text { Promotions and } \\
\text { advertising }\end{array}$} & Asia & 4.20 & 1.01 & 2 & 3.50 & 5 & 5.00 & 5 & \multirow{4}{*}{$\begin{aligned} \mathrm{H} & =1.54 \\
p & =0.67\end{aligned}$} & & 1 & 1 & 1 \\
\hline & $\mathrm{EU}$ & 4.03 & 1.07 & 1 & 3.00 & 4 & 5.00 & 5 & & 1 & & 1 & 1 \\
\hline & N. America & 3.89 & 1.23 & 1 & 3.00 & 4 & 5.00 & 5 & & 1 & 1 & & 1 \\
\hline & Other & 3.50 & 1.51 & 1 & 2.75 & 3.5 & 5.00 & 5 & & 1 & 1 & 1 & \\
\hline
\end{tabular}




\section{Discussion and Conclusions}

Value co-creation and customer involvement in this process are key attributes of the organizations seeking to succeed on the market (Prahalad and Ramaswamy 2004; Yang et al. 2014; Hsieh and Hsieh 2015). Seger-Guttmann et al. (2017) researched the notion of country of origin and its impact on customer satisfaction, but the academics focused on post-transaction surveys in service organizations. Another paper concentrating on the customer's country of origin was connected with cultural influences on evaluations of service quality (Albu 2013; Guesalaga et al. 2016). Najafi-Tavani et al. (2020) have verified how the cultural distance influences relationship learning on international customer involvement in manufacturing enterprises in China. They found out that the relationship learning capabilities are much more beneficial for manufacturers when their culture is similar to the customers' one, and that cultural differences importantly reduce the effectiveness of international customer involvement on company performance. However, we found no studies exploring the dependence of country of origin on international customer satisfaction in technology-based firms. Due to the lack of research among the technology-based companies, especially in the airsoft industry, our study brings valuable insights for both theoreticians as well as for practitioners. For academics, it highlights the necessity of verifying the impact of country-of-origin not only in service industries, but also in manufacturing industries, which have been omitted so far. Researchers tend to pay attention to the country-of-origin effect concentrating on the product origin, not the users' one (Montanari et al. 2018; Sevanandee and Damar-Lakadoo 2018). Moreover, this paper contributes much to the methodology of the research, as it suggests the employment of the Kruskal-Wallis's Test and post-hoc (Dunn-Bonferroni) test in order to verify the impact of the geographical area of origin on the evaluation of measures of customer satisfaction. Furthermore, the results of our study contribute to a better understanding of the factors leading to customer satisfaction involved in the process of value co-creation in the airsoft industry.

There is also a substantial contribution of the research for practitioners who operate in the manufacturing industry. In the case of GATE, technology commercialization is considered in the context in which it is a result of collaboration and knowledge integration of, not two companies, but a company and customer (Wouters and Kirchberger 2015). It stems from the fact that a key success factor for new technology is connected with the benefits that it will deliver to users (Galbraith et al. 2006). Firstly, as the analyzed company puts a lot of effort into value co-creation and even hires some of its customers, the obtained results let the company improve its marketing strategy and had significant impact on raising GATE's sales. The study revealed the most important factors influencing customer satisfaction in the airsoft industry. The evaluation of factors gave the company direct hints on what it should focus on in order to satisfy customers and meet their needs. The crucial factors encompass the quality level, product functionality and after-sales service. The least important aspects included the packaging, brand name and price. The results sketched the direction of the company's strategic plan and were the basis of its marketing activities. Moreover, the research proved that the assumption about the dependence of satisfaction factors on the geographical area of respondents' origin is false. This is a very important hint for all managers who run companies in the airsoft industry and sell on global markets. Thanks to the research, they will not waste their valuable time and energy wondering if they should target their marketing activities by taking into consideration cultural differences, as they will be aware that such differences do not have a significant impact, at least with regard to customers' continental division into Asia, European Union, North America and others.

Summarizing the above study, much attention is needed in the context of cooperation between academics and practitioners, especially in the fields of entrepreneurship, marketing and management. Managers of airsoft companies frequently lack specific academic knowledge, which would enable them to run adequate marketing campaigns and design good strategic plans. They wonder whether their companies, operating globally, should target international customers in the same way, or invest in diversifying their marketing actions depending on geographical origin. The paper is the first step towards simplifying the work of practitioners running entrepreneurial companies in the airsoft industry. 
Our study has several limitations. One of them is that the survey was performed among the existing firm's customers. So, our results are based on the customers who knew the brand and had experience with GATE's products. It would be valuable to perform a study using random airsoft players who are not familiar with the company. Furthermore, it would be valuable to verify whether there is any correlation between the customers' evaluation of the factors influencing customer satisfaction and their specific country-of-origin, instead of division into the geographical areas. This would be valuable, especially for the companies that sell to a smaller number of countries than GATE does. Such research could be carried out based on customers' evaluation of factors in other companies than GATE, but still operating in the airsoft industry. In addition, valuable feedback would be gathered from airsoft stores and distributors with which GATE directly cooperates. Moreover, it would be interesting to compare the results on customer satisfaction with those customers who were not involved in the process of value co-creation. This group would be treated as a control group in order to validate the obtained results. Future studies would include longitudinal study, other qualitative research methods, developing a model and more cases, other multi-dimensional in-depth studies, or comparative case studies testing the validity of the proposed conceptual framework in other industries. Moreover, further research may examine firms that have high and low customer satisfaction or might be based on interviews with people in the firms in order to understand their assumptions and how they line up with customer demands.

Author Contributions: Conceptualization, G.M. and M.S.; Data curation, M.S.; Formal analysis, G.M. and M.S.; Funding acquisition, M.S.; Investigation, G.M.; Methodology, G.M.; Software, G.M.; Supervision, M.S.; Validation, G.M.; Visualization, G.M.; Writing_original draft, G.M.; Writing—review \& editing, M.S. All authors have read and agreed to the published version of the manuscript.

Funding: The APC was funded by the Cracow University of Economics, grant number 057/WE-KAS/01/2019/S/9057.

Conflicts of Interest: The authors declare no conflict of interest. The funders had no role in the design of the study; in the collection, analyses, or interpretation of data; in the writing of the manuscript, or in the decision to publish the results.

\section{Appendix A}

Survey questions.

Airsoft Mosfets Survey.

Dear Airsofters!

Would you like to get a $20 \%$ discount at GATE online store gatee.eu or just help us make better products? All you need to do is to fill out the anonymous survey, which takes up to $20 \mathrm{~min}$. The $-20 \%$ coupon code is valid till the end of May 2017. The survey is available till 23rd of April 2017.

This survey has been prepared in order to make you a creator of the airsoft world. By answering a few simple questions, you will impact the direction in which the airsoft technology moves. Now, you are the one who holds power to influence the future of airsoft. Share with us your unique experience to help develop the best products, and then enjoy your hobby even more!

Introduce Yourself.

1. Country.

2. Age.
(a) $<18$.
(b) $\quad 19-25$.
(c) $26-30$.
(d) $31-40$.
(e) $\quad 41<$.

3. Gender. 

(a) Male.
(b) Female.

4. Education.
(a) Secondary.
(b) Higher (post-secondary).
(c) Doctoral.

5. Salary (monthly in USD).
(a) $\quad<500$.
(b) \$501-\$1000.
(c) \$1001-\$2500.
(d) \$2501-\$3999.
(e) $\$ 4000-\$ 5999$.
(f) $\$ 6000<$.

6. How much do you spend on airsoft hobby (yearly in USD):
(a) $\quad<\$ 500$
(b) \$501-\$1500.
(c) \$1501-\$3000.
(d) $\$ 3001-\$ 5000$.
(e) $\$ 5000<$.

7. How often do you play airsoft:
(a) Less than once a month.
(b) 1-2 times per month.
(c) 3-5 times per month.
(d) 6-8 times per month.
(e) More than 9 times per month.

Products and Functions.

8. Which of the GATE products do you have experience with?
(a) TITAN.
(b) WARFET
(c) NanoHARD.
(d) PicoAAB
(e) NanoAAB
(f) NanoASR.
(g) MERF 3.2.
(h) NanoSSR.
(i) PicoSSR 3.
(j) None.

9. Rate the product attributes (1-unnecessary, 2-not so important, 3-important, 4-necessary, 5 - extremely necessary).

- $\quad$ Trigger sensitivity adjustment.

- Configurable fire selector.

- Non-adjustable pre-cocking. 
- Adjustable pre-cocking.

- 3-rd burst.

- Configurable burst (two to 10 rounds).

- Rate of fire reduction.

- Decreasing wear and tear of Airsoft Electric Gun (AEG) internal parts.

- Setting delay between each semishots to simulate the delay from reload or recoil.

- Two stage trigger [AUG (germ. Armee Universal Gewehr-"universal army rifle") Mode].

- 'MOSFET' reliability (internal protections).

- Low battery warning.

- Prolonging the lifespan of the motor.

- Diagnostic trouble codes.

- Resistance to atmospheric conditions.

- Resistance to water immersion.

- Built-in deans-t connectors.

- Included Mini-tamiya adapter.

- Compatibility with $14.8 \mathrm{~V}$ lithium polymer (LI-PO) batteries.

- Complete wiring with trigger contacts.

- Functions adjustment via button and LED display.

- Functions adjustment via USB-Link and computer app.

- Functions adjustment via programmer (programming card).

10. Rate each of the following MOSFET improvements according to your needs (1- unnecessary, 2not so important, 3-important, 4-necessary, 5-extremely necessary).

- In case of incorrectly connecting positive and negative battery terminals (reverse polarity), the MOSFET, motor and installation will be protected against damage.

- Functions adjustment via Bluetooth and smartphone app.

- Bolt-catch function (if there is no airsoft pellets (BBs) in your magazine, your AEG cannot fire a shot).

- $\quad$ The BBs counter (you exactly know how many BBs are currently in your magazine).

Do you have any ideas for future MOSFET improvements? (open answer).

Manuals

11. Do you think the GATE TITAN manual is detailed enough? Please skip the question if you did not see the TITAN manual.

(1-too less information; 10 - too much information).

12. Rate the types of manuals according to your preferences.

- Written manuals (1-I dislike written manuals; 5-I like written manuals).

- Tutorial videos (1-I never watch tutorial videos; 5-I always watch tutorial videos).

- Printed quickstart in product kit is. (1-unnecessary; 5- extremely necessary).

Price

13. Taking into consideration the product quality, functions, features and reliability, is the price of TITAN Complete Set adequate to the product value?

(a) YES, the price is adequate.

(b) NO, the price is too high. 
(c) I am happy I can pay less, but I think that so advanced product would cost more.

(d) I do not know the TITAN product.

14. What do you think would be the most fair price for TITAN Complete Set? (Please skip this question if you do not know the TITAN product).

15. How big a factor is price in your decision-making process? (1-price is not important for me; 5-price is extremely important for me).

16. Finish the sentence: I would like to.

(a) pay higher price and have more advanced drop-in MOSFET with many functions.

(b) pay less and have a simple version of drop-in MOSFET.

17. How does GATE rate in terms of price? (1-cheap taking into consideration quality, 5-very expensive).

Gate.

18. Do you trust in GATE brand and GATE company? (1-I do not trust GATE, 5-I totally trust GATE).

19. Rate the risks that you may perceive when choosing GATE company (1-no risk, 2-low risk, 3-moderate risk, 4-high risk, 5-very high risk).

- Installation concerns.

- Product failure.

- Difficult product usage.

- $\quad$ Lack of technical support.

Are there any other risks you might perceive when choosing GATE?

20. What do you consider a substitute for GATE product?

21. Airsoft.

22. What trends do you see coming in airsoft?

23. What irritates you as an airsofter?

24. Rate the factors influencing how much fun you have playing airsoft (1-not important, 5 -extremely important).

- Realism.

- Airsoft field.

- Friends.

- Weather.

- Airsoft gun.

- Equipment.

- Fairness.

25. Rate the attributes of airsoft gun (1-not important, 5-extremely important).

- $\quad$ Range (Feet per second-FPS).

- Rate of fire.

- Trigger response.

- Option to adjust AEG with advanced MOSFET.

26. Why do you play airsoft? Rate reasons according to the level of impact on your decision to play airsoft. (-low impact, 5-high impact).

I play airsoft... 
- To get entertained.

- For training.

- To show off.

- Because airsoft is a better alternative to FPS games.

- To check myself.

- To compete.

27. Had you liked FPS games before you started playing airsoft? (1-I hadn't liked FPS games before started playing airsoft, 5-I had loved playing FPS before started playing airsoft).

Satisfaction.

28. Rate each of the elements according to the importance (1-not important, 5-extremely important).

- Brand name.

- Product functionality.

- Quality level.

- Packaging.

- Design (how the product looks like).

- Warranty period.

- After-sales service.

- Manuals (user-friendly and multilingual).

- Company website.

- Tutorial videos.

- Ease of installation.

- Promotions and advertising (e.g., discounts at online store).

\section{References}

Acocella, Angela, and Feng Zhu. 2017. X Fire Paintball \& Airsoft: Is Amazon a Friend or Foe (A)? Harvard Business School Cases 617: 1-15.

Agrawal, Amit Kumar, and Zillur Rahman. 2015. Roles and resource contributions of customers in value co-creation. International Strategic Management Review 3: 144-60. [CrossRef]

Aitken, Alan, and Robert Paton. 2016. Professional buyers and the value proposition. European Management Journal 34: 223-31. [CrossRef]

Akaka, Melissa Archpru, and Stephen L. Vargo. 2014. Technology as an operant resource in service (eco) systems. Information Systems and e-Business Management 12: 367-84. [CrossRef]

Alavi, Maryam, and Dorothy E. Leidner. 2001. Review: Knowledge management and knowledge management systems: Conceptual foundations and research issues. MIS Quarterly 25: 107-36. [CrossRef]

Albu, Cristina Elena. 2013. Stereotypical Factors in Tourism. Cross-Cultural Management Journal 15: 5-14.

Alshanty, Abdallah Mohammad Alshanty, and Okechukwu Lawrence Emeagwali. 2019. Market-sensing capability, knowledge creation and innovation: The moderating role of entrepreneurial-orientation. Journal of Innovation \& Knowledge 4: 171-78.

Anderson, James C., Dipak C. Jam, and Pradeep K. Chintagunta. 1993. Customer value assessment in business markets: A state-of-practice study. Journal of Business to Business Marketing 1: 3-29. [CrossRef]

Banyte, Jurate, and Aiste Dovaliene. 2014. Relations between customer engagement into value creation and customer loyalty. Procedia-Social and Behavioral Sciences 156: 484-89. [CrossRef]

Barnes, Cindy, Helen Blake, and David Pinder. 2009. Creating and delivering your value proposition: Managing customer experience for profit. In Creating and Delivering Your Value Proposition: Managing Customer Experience for Profit. Edited by Cindy Barnes, Helen Blake and David Pinder. Philadelphia: Kogan Page Ltd., pp. 21-41. Berawi, Mohammed Ali, and Roy Woodhead. 2020. Value Creation and the Pursuit of Multi Factor Productivity Improvement. International Journal of Technology 11: 111-22. 
Bower, Marvin, and Robert A. Garda. 1985. The role of marketing in management. The McKinsey Quarterly 3: 34-46.

Bowman, Cliff, and Veronique Ambrosini. 2000. Value creation versus value capture: Towards a coherent definition of value in strategy. British Journal of Management 11: 1-15. [CrossRef]

Boyce, Byrl. 1975. Real Estate Appraisal Terminology. In Real Estate Appraisal Terminology. Edited by Byrl Boyce. Chicago: American Institute of Real Estate Appraisers and the Society of Real Estate Appraisers, p. 137.

Breidbach, Christoph F., and Paul P. Maglio. 2016. Technology-enabled value co-creation: An empirical analysis of actors, resources, and practices. Industrial Marketing Management 56: 73-85. [CrossRef]

Brown, Jo, Amanda Broderick, and Nick Lee. 2007. Word of mouth communication within online communities: Conceptualizing the online social network. Journal of Interactive Marketing 21: 2-20. [CrossRef]

Camlek, Victor. 2010. How to spot a real value proposition. Information Services \& Use 30: 119-23.

Chatain, Olivier. 2011. Value creation, competition, and performance in buyer-supplier relationships. Strategic Management Journal 32: 76-102. [CrossRef]

Cohen, David, Christopher Gan, Hua Hwa Au Yong, and Esther Choong. 2006. Customer satisfaction: A study of bank customer retention in New Zealand. Discussion Paper: Lincoln University Catenbury 109: 1-14.

Cossío-Silva, Francisco José, María Ángeles Revilla-Camacho, Manuela Vega-Vázquez, and Beatriz Palacios-Florencio. 2016. Value co-creation and customer loyalty. Journal of Business Research 69: 1621-25. [CrossRef]

Covin, Jeffrey G., Robert P. Garrett, Donald F. Kuratko, and Dean A. Shepherd. 2015. Value proposition evolution and the performance of internal corporate ventures. Journal of Business Venturing 30: 749-74. [CrossRef]

Cunningham, James A., Matthias Menter, and Conor O'Kane. 2018. Value creation in the quadruple helix: A micro level conceptual model of principal investigators as value creators. RED Management 48: 136-47.

Davenport, Thomas H., and Laurence Prusak. 1998. Working knowledge: How organizations manage what they know. In Working knowledge: How Organizations Manage what they Know. Edited by Thomas H. Davenport and Laurence Prusak. Boston: Harvard Business School Press.

Davila, Tony. 2000. An empirical study on the drivers of management control systems design in new product development. Accounting, Organizations and Society 25: 383-409. [CrossRef]

Deng, Qi. 2019. Blockchain Economical Models, Delegated Proof of Economic Value and Delegated Adaptive Byzantine Fault Tolerance and their implementation in Artificial Intelligence BlockCloud. Journal of Risk and Financial Management 12: 177. [CrossRef]

Do Duc, Linh, Vladimir Horák, Tomas Lukáč, Roman Vítek, and Quang Huy Mai. 2016. Dynamics of knock-open valve for gas guns powered by carbon dioxide. Proceedings of the Scientific Conference AFASES 1: 323-30.

Dyduch, Wojciech. 2019. Entrepreneurial Strategy Stimulating Value Creation: Conceptual Findings and Some Empirical Tests. Entrepreneurial Business \& Economics Review 7: 65-82.

Etgar, Michael. 2008. A descriptive model of the consumer co-production process. Journal of the Academy of Marketing Science 36: 97-108.

Fornell, Claes. 1992. A national customer satisfaction barometer: The Swedish experience. Journal of Marketing 56: 6-21.

Frow, Pennie, and Adrian Payne. 2011. A stakeholder perspective of the value proposition concept. European Journal of Marketing 45: 223-40.

Frow, Pennie, and Adrian Payne. 2014. Developing superior value propositions: A strategic marketing imperative. Journal of Service Management 25: 213-27.

Galbraith, Craig S., Sanford Ehrlich, and Alex DeNoble. 2006. Predicting technology success: Identifying Key predictors and assessing expert evaluation for advanced technologies. The Journal of Technology Transfer 31: 673-84.

Galvagno, Marco, and Daniele Dalli. 2014. Theory of value co-creation: A systematic literature review. Managing Service Quality 24: 643-83.

Giese, Joan L., and Joseph A. Cote. 2000. Defining consumer satisfaction. Academy of Marketing Science Review 1: $1-24$.

Goedhart, Marc, Tim Koller, and David Wessels. 2015. Valuation: Measuring and Managing the Value of Companies. In Valuation: Measuring and Managing the Value of Companies. Edited by Marc Goedhart, Tim Koller and David Wessels. New Jersey: John Wiley \& Sons.

Gray, Rob. 2006. Social, environmental and sustainability reporting and organisational value creation? Whose value? Whose creation? Accounting, Auditing \& Accountability Journal 19: 793-819. 
Groen, Aard, Gary Cook, and Peter Van der Sijde. 2015. New technology-based firms in the new millennium. In New Technology-Based Firms in the New Millennium. Edited by Aard Groen, Gary Cook and Peter Van der Sijde. Bingley: Emerald Group Publishing.

Gronroos, Christian, and Paivi Voima. 2013. Critical service logic: Making sense of value creation and Co-creation. Journal of the Academy of Marketing Science 41: 133-50. [CrossRef]

Guesalaga, Rodrigo, Daiane Scaraboto, and Meghan Pierce. 2016. Cultural influences on expectations and evaluations of service quality in emerging markets. International Marketing Review 33: 88-111. [CrossRef]

Gupta, Sunil, and Donald Lehman. 2005. Managing Customers as Investments. Chennai: Pearson Education India, vol. 28, pp. 1-8.

Haavisto, Anna-Kaisa, Ahmad Sahraravand, Paivi Puska, and Tiina Leivo. 2019. Toy gun eye injuries-Eye protection needed Helsinki ocular trauma study. Acta Ophthalmologica 97: 430-34. [CrossRef]

Hareli, Shlomo, and Ursula Hess. 2012. The social signal value of emotions. Cognition E Emotion 26: 385-89.

He, Ying, and Dawei Zhang. 2019. Manager's Characteristics, Debt Financing and Firm Value. China Economist 14: 96-110.

Horák, Vladimir, Linh Duc, Roman Vítek, S. Beer, and Quang Huy Mai. 2014. Prediction of the air gun performance. Advances in Military Technology 9: 31-44.

Howard, Nicholas. 2011. Marx's theory of price and its modern rivals. In Marx's Theory of Price and Its Modern Rivals. Edited by Nicholas Howard. London: Palgrave Macmillan.

Hsieh, Jung Kuei, and Yi Ching Hsieh. 2015. Dialogic co-creation and service innovation performance in high-tech companies. Journal of Business Research 68: 2266-71. [CrossRef]

Jaki, Andrzej, and Barbara Siuta-Tokarska. 2019. New imperative of corporate value creation in face of the challenges of sustainable development. Entrepreneurial Business E Economics Review 7: 63-81.

Jean, Ruey-Jer (Bryan), Rudolf R. Sinkovics, and S. Tamer Cavusgil. 2010. Enhancing International Customer-Supplier Relationships through IT Resources: A Study of Taiwanese Electronics Suppliers. Journal of International Business Studies 41: 1218-39. [CrossRef]

Jo, Adekannbi, and Aje Mo. 2018. Factors influencing customer satisfaction and loyalty to internet banking services among undergraduates of a Nigerian University. The Journal of Internet Banking and Commerce 23: 1-21.

Kambil, Ajit, Ari Ginsberg, and Michael Bloch. 1996. Re-Inventing Value Propositions. Working Paper no. 2451/14205. New York: New York University.

Kaplan, Robert S., and David P. Norton. 2004. Strategy maps: Converting intangible assets into tangible outcomes. In Strategy Maps: Converting Intangible Assets into Tangible Outcomes. Edited by Robert S. Kaplan and David P. Norton. Boston: Harvard Business Press, p. 10.

Kelty, Logan. 2013. Let's Make a Deal: The Exchange Value of Advertising. International Journal of Integrated Marketing Communications 5: 7-23.

Kessler, Eric, Paul Bierly, and Shanthi Gopalakrishnan. 2001. Vasa syndrome: Insights from a 17th-century new-product disaster. Academy of Management Executive 15: 80-91.

Khan, Muhammad Asad. 2019. The Perception of the Customers toward Social Media Marketing: Evidence from Local and International Media Users. Journal of Managerial Sciences 13: 117-29.

Kowalkowski, Christian, Oscar P. Ridell, Jimmie G. Röndell, and David Sörhammar. 2012. The co-creative practice of forming a value proposition. Journal of Marketing Management 28: 1553-70. [CrossRef]

Lanning, Michaels, and Edward Michaels. 1988. A business is a value delivery system. McKinsey Staff Paper 41: 1-16.

Lanning, Michael. 1998. Delivering Profitable Value. In Delivering Profitable Value. Edited by Michael Lanning. Cambridge: Perseus Publishing.

Lepak, David P., Ken G. Smith, and M. Susan Taylor. 2007. Value creation and value capture: A multilevel perspective. Academy of Management Review 32: 180-94. [CrossRef]

Lerro, Antonio. 2011. A stakeholder-based perspective in the value impact assessment of the project valuing intangible assets in Scottish renewable SMEs. Measuring Business Excellence 15: 3-15. [CrossRef]

Luchs, Michael G., K. Scott Swan, and Marielle E. H. Creusen. 2016. Perspective: A review of marketing research on product design with directions for future research. Journal of Product Innovation Management 33: 320-41. [CrossRef]

McGee, Ashley. 2017. Advancing airguns \& airsoft sales. Shooting Industry 50: 38-40. 
Menguc, Bulent, Seigyoung Auh, and Peter Yannopoulos. 2014. Customer and supplier involvement in design: The moderating role of incremental and radical innovation capability. Journal of Product Innovation Management 31: 313-28. [CrossRef]

Montanari, Gabriela Maria, Mateus Jonny Rodrigues, Janaina de Moura Engracia Giraldi, and Marcos Fava Neves. 2018. Country of origin effect: A study with Brazilian consumers in the luxury market. Brazilian Business Review (English Edition) 15: 348-62. [CrossRef]

Morris, Michael, Minet Schindehutte, and Jeffrey Allen. 2005. The entrepreneur's business model: Toward a unified perspective. Journal of Business Research 58: 726-35. [CrossRef]

Najafi-Tavani, Zhaleh, Sahar Mousavi, Ghasen Zaefarian, and Peter Naudé. 2020. Relationship learning and international customer involvement in new product design: The moderating roles of customer dependence and cultural distance. Journal of Business Research 120: 42-58. [CrossRef]

Nickerson, Jackson, Brian S. Silverman, and Todd R. Zenger. 2007. The problem of creating and capturing value. Strategic Organisation 5: 211-25. [CrossRef]

Nonaka, Ikujiro, and Hirotaka Takeuchi. 1995. The knowledge-creating company: How Japanese companies create the dynamics of innovation. In The Knowledge-Creating Company: How Japanese Companies Create the Dynamics of Innovation. Edited by Ikujiro Nonaka and Hirotaka Takeuchi. New York: Oxford University Press.

Olivier, Richard L. 1980. A cognitive model of the antecedents and consequences of satisfaction decisions. Journal of Marketing Research 17: 460-69. [CrossRef]

Osterwalder, Alex, Yves Pigneur, Greg Bernarda, and Alan Smith. 2014. Value Proposition Design. In Value Proposition Design. Edited by Alex Osterwalder, Yves Pigneur, Greg Bernarda and Alan Smith. Hoboken: John Wiley \& Sons, Inc., p. 48.

Pattarakitham, Amornrat. 2015. The Factors Influence Customer Satisfaction and Loyalty: A Study of Tea Beverage in Bangkok. Paper presented at the XIV International Business and Economy Conference (IBEC), Bangkok, Thailand, January 5-8.

Payne, Adrian, and Sue Holt. 2001. Diagnosing customer value: Integrating the value process and relationship marketing. British Journal of Management 12: 159-82. [CrossRef]

Pluta-Olearnik, Mirosława. 2016. Marketing Communication in the Process of University Internationalisation. Handel Wewnętrzny 3: 266-75.

Prahalad, Coimbatore Krishnarao, and Venkatram Ramaswamy. 2000. Co-opting customer competence. Harvard Business Review 78: 79-90.

Prahalad, Coimbatore Krishnarao, and Venkatram Ramaswamy. 2004. Co-creating unique value with customers. Strategy \& Leadership 32: 4-9.

Prahalad, Coimbatore Krishnarao, and Venkatram Ramaswamy. 2013. The Future of Competition: Co-Creating Unique Value with Customers. In The Future of Competition: Co-Creating Unique Value with Customers. Edited by Coimbatore Krishnarao Prahalad and Venkatram Ramaswamy. Boston: Harvard Business Press.

Priem, Richard L. 2007. A consumer perspective on value creation. Academy of Management Review 32: $219-35$. [CrossRef]

Riihimäki, Tapio, Valtteri Kaartemo, and Peter Zettinig. 2016. Co-evolution of dynamic capabilities and value propositions from a process perspective. Advances in Business-Related Scientific Research Journal 7: 64-76.

Roşu, Daniel. 2015. Participants Profile in Airsoft Sport. Procedia-Social and Behavioral Sciences 180: $1316-21$.

Rozian Sanib, Noor Izza, Yuhaniz Abdul Aziz, Zaiton Samdin, and Khalid Ab Rahim. 2013. Comparison of Marketing Mix Dimensions between Local and International Hotel Customers in Malaysia. International Journal of Economics \& Management 7: 297-313.

Saha, Victor, Venkatesh Mani, and Praveen Goyal. 2020. Emerging trends in the literature of value co-creation: A bibliometric analysis. Benchmarking: An International Journal 27: 981-1002. [CrossRef]

Sánchez-Fernández, Raquel, and M. Ángeles Iniesta-Bonillo. 2007. The concept of perceived value: A systematic review of the research. Marketing Theory 7: 427-51. [CrossRef]

Saunte, Jon Peiter, and Mads Egil Saunte. 2006. 33 cases of airsoft gun pellet ocular injuries in Copenhagen, Denmark, 1998-2002. Acta Ophthalmologica Scandinavica 84: 755-58. [CrossRef]

Saunte, Jon Peiter, and Mads Egil Saunte. 2008. Childhood ocular trauma in the Copenhagen area from 1998 to 2003 : Eye injuries caused by airsoft guns are twice as common as firework-related injuries. Acta Ophthalmologica Scandinavica 86: 345-47. [CrossRef] 
Scridon, Mircea Andrei, Sorin Adrian Achim, Mirela-Oana Pintea, and Marius Dan Gavriletea. 2019. Risk and perceived value: Antecedents of customer satisfaction and loyalty in a sustainable business model. Economic Research-Ekonomska Istraživanja 32: 909-24. [CrossRef]

Seger-Guttmann, Tali, Iris Vilnai-Yavetz, and Mark S. Rosenbaum. 2017. Disparate satisfaction scores? Consider your customer's country-of-origin: A case study. The International Review of Retail, Distribution and Consumer Research 27: 189-206. [CrossRef]

Servera-Francés, David, and Lidia Piqueras-Tomás. 2019. The effects of corporate social responsibility on consumer loyalty through consumer perceived value. Economic Research-Ekonomska Istraživanja 32: 66-84. [CrossRef]

Sevanandee, Brenda, and Adjnu Damar-Lakadoo. 2018. Country-of-Origin Effects on Consumer Buying Behaviours. A Case of Mobile Phones. Studies in Business \& Economics 13: 179-201.

Sideri, Katerina, and Andreas Panagopoulos. 2018. Setting up a Technology Commercialization Office at a Non-entrepreneurial University: An Insider's Look at Practices and Culture. Journal of Technology Transfer 43: 953-65. [CrossRef]

Swamidass, Paul M. 2012. University startups as a commercialization alternative: Lessons from three contrasting case studies. The Journal of Technology Transfer 38: 788-808. [CrossRef]

Szarucki, Marek, and Gabriela Menet. 2018. Service marketing, value co-creation and customer satisfaction in the airsoft industry: Case of a technology-based firm. Business, Management and Education 16: 94-107. [CrossRef]

Van der Merwe, Carmen, Antonie van Rensburg, and Cornelius Stephanus L. Schutte. 2015. An engineering approach to an integrated value proposition design framework. South African Journal of Industrial Engineering 26: 59-74. [CrossRef]

Vargo, Stephen L., and Robert F. Lusch. 2004. Evolving to a new dominant logic for marketing. Journal of Marketing 68: 1-17. [CrossRef]

Wang, Chen-Ya, Li Miao, and Anna S. Mattila. 2015. Customer responses to intercultural communication accommodation strategies in hospitality service encounters. International Journal of Hospitality Management 51: 96-104. [CrossRef]

Wang, Xiaobei, Goran Persson, and Lars Huemer. 2016. Logistics service providers and value creation through collaboration: A case study. Long Range Planning 49: 117-28. [CrossRef]

Woodruff, Robert. 1997. Customer Value The Next Source of Competitive Advantage. Journal of the Academy of Marketing Science 25: 139-53. [CrossRef]

Wouters, Marc, and Markus A. Kirchberger. 2015. Customer value propositions as inter-organizational management accounting to support customer collaboration. Industrial Marketing Management 46: 54-67. [CrossRef]

Yang, Ching-Chow, and Dylan Sung. 2011. An integrated model of value creation based on the refined Kano's model and the Blue Ocean strategy. Total Quality Management \& Business Excellence 22: 925-40.

Yang, Ching-Chow, Ping-Shun Chen, and Yu-Hui Chien. 2014. Customer expertise, affective commitment, customer participation, and loyalty in B\&B services. International Journal of Organizational Innovation 6: 174-83.

Yang, Ching-Chow. 2005. The Refined Kano's Model and its Application. Total Quality Management 16: 1127-37. [CrossRef]

Yin, Robert K. 2009. Case Study Research: Design and Methods, 4th ed. London: SAGE.

(C) 2020 by the authors. Licensee MDPI, Basel, Switzerland. This article is an open access article distributed under the terms and conditions of the Creative Commons Attribution (CC BY) license (http://creativecommons.org/licenses/by/4.0/). 